\title{
Square-planar rhodium(I) complexes with aromatic bent terdentate nitrogen ligands as candidates for rod-like extended materials $\dagger$
}

\author{
Jean-Marc Bénech, ${ }^{a}$ Claude Piguet, ${ }^{* a}$ Gérald Bernardinelli, ${ }^{b}$ Jean-Claude G. Bünzli ${ }^{c}$ and \\ Gérard Hopfgartner ${ }^{d}$ \\ a Department of Inorganic, Analytical and Applied Chemistry, University of Geneva, 30 quai \\ E. Ansermet, CH-1211 Geneva 4, Switzerland.E-mail: Claude.Piguet@chiam.unige.ch \\ ${ }^{b}$ Laboratory of X-ray Crystallography, 24 quai E. Ansermet, CH-1211 Geneva 4, Switzerland \\ ${ }^{c}$ Institute of Inorganic and Analytical Chemistry, University of Lausanne, BCH 1402, \\ CH-1015 Lausanne, Switzerland \\ ${ }^{d}$ F. Hoffmann-La Roche Ltd, Pharmaceuticals Division, PRNS 68/142, CH-4070 Basle, \\ Switzerland
}

Received 10th November 2000, Accepted 20th December 2000

First published as an Advance Article on the web 15th February 2001

\begin{abstract}
The crystal structure of 2,6-bis(1-methylbenzimidazol-2-yl)pyridine $\left(\mathrm{L}^{4}\right)$ evidenced a quasi trans-trans conformation of the unsubstituted nitrogen atoms of the aromatic rings which is maintained in solution on the NMR timescale. Reactions of $\mathrm{L}^{4}$, or of its lipophilic analogue 2,6-bis(1-octylbenzimidazol-2-yl)pyridine $\left(\mathrm{L}^{5}\right)$, with $[\mathrm{Rh}(\mathrm{NBD}) \mathrm{Cl}]_{2}$ $\left(\mathrm{NBD}=\right.$ bicyclo[2.2.1] hepta-2,5-diene) produced poorly soluble dimetallic complexes $\left[\{\mathrm{Rh}(\mathrm{NBD}) \mathrm{Cl}\}_{2} \mathrm{~L}^{i}\right](i=4$ or 5$)$. The crystal structure of $\left[\left\{\mathrm{Rh}(\mathrm{NBD}) \mathrm{Cl}_{2} \mathrm{~L}^{5}\right]\right.$ revealed that the terdentate aromatic unit adopts a distorted trans-trans conformation and acts as a bridging ligand connecting two $[\mathrm{Rh}(\mathrm{NBD}) \mathrm{Cl}]$ units through the nitrogen atoms of the benzimidazole side arms. Solution studies (ES-MS, NMR) indicate that (i) the dimetallic structure is maintained in solution, (ii) the complicated fluxional behaviour observed at room temperature is blocked at $210 \mathrm{~K}$ on the NMR timescale and (iii) the bent aromatic core cannot act as a meridional terdentate chelate toward $\mathrm{Rh}^{\mathrm{I}}$. The consequences of this co-ordination behaviour on the molecular anisometry of extended complexes is discussed.
\end{abstract}

\section{Introduction}

Until 1996, ${ }^{1}$ no example of calamitic metallomesogens (i.e. metal-containing liquid crystals) involving terdentate binding units had been reported, while only few discotic metallomesogens with terdentate 1,3,5-triketonate, ${ }^{2}$ 1,4,7-triazacyclonane $^{3}$ and pyridine-2,6-dimethanol ${ }^{4}$ ligands have been described. Recently, two concomitant approaches have been developed for introducing bent terdentate binding units into rod-like receptors exhibiting mesomorphism. The first approach uses the connection of semi-rigid lipophilic long chains connected to the 4 position of the central pyridine unit in 6'-phenyl-2,2'-bipyridine, ${ }^{5}$ pyridine-2,6-dicarboxylic acids and pyridine-2,6-dithiocarboxylic acids ${ }^{6}$ in order to induce significant molecular anisometry compatible with calamitic mesomorphism. Nematic, ${ }^{5}$ smectic and columnar ${ }^{6}$ mesophases have been detected at high temperature for the ligands and for their rigid tabular complexes with square-planar $\mathrm{Pd}^{\mathrm{II}}$ in which partial or complete charge compensation results from orthometallation $^{5}$ or deprotonation. ${ }^{6}$ On the other hand, neutral aromatic bent terdentate binding units incorporated into extended aromatic receptors offer fascinating perspectives for the preparation of fast-switching ferro- or antiferro-electric mesophases. ${ }^{7}$ Rod-like $\left(\mathrm{L}^{1}\right)^{8}$ and banana-shaped $\left(\mathrm{L}^{2}\right)^{9}$ receptors (see Scheme 1) containing bent 2,6-bis(1-ethylbenzimidazol-2yl)pyridine cores display respectively calamitic (smectic and nematic) ${ }^{8}$ and columnar mesomorphism, ${ }^{10}$ but meridional three-co-ordination of the central binding unit to $\mathrm{Ln}\left(\mathrm{NO}_{3}\right)_{3}$

$\uparrow$ Electronic supplementary information (ESI) available: tables of selected bond distances and angles for $\mathrm{L}^{4}$ and selected least-squares plane data for $\left[\left\{\mathrm{Rh}(\mathrm{NBD}) \mathrm{Cl}_{2} \mathrm{~L}^{5}\right] \mathbf{2}\right.$. Figures showing intermolecular packing in $\mathrm{L}^{4}$ and in 2. See http://www.rsc.org/suppdata/dt/b0/ b009051o/

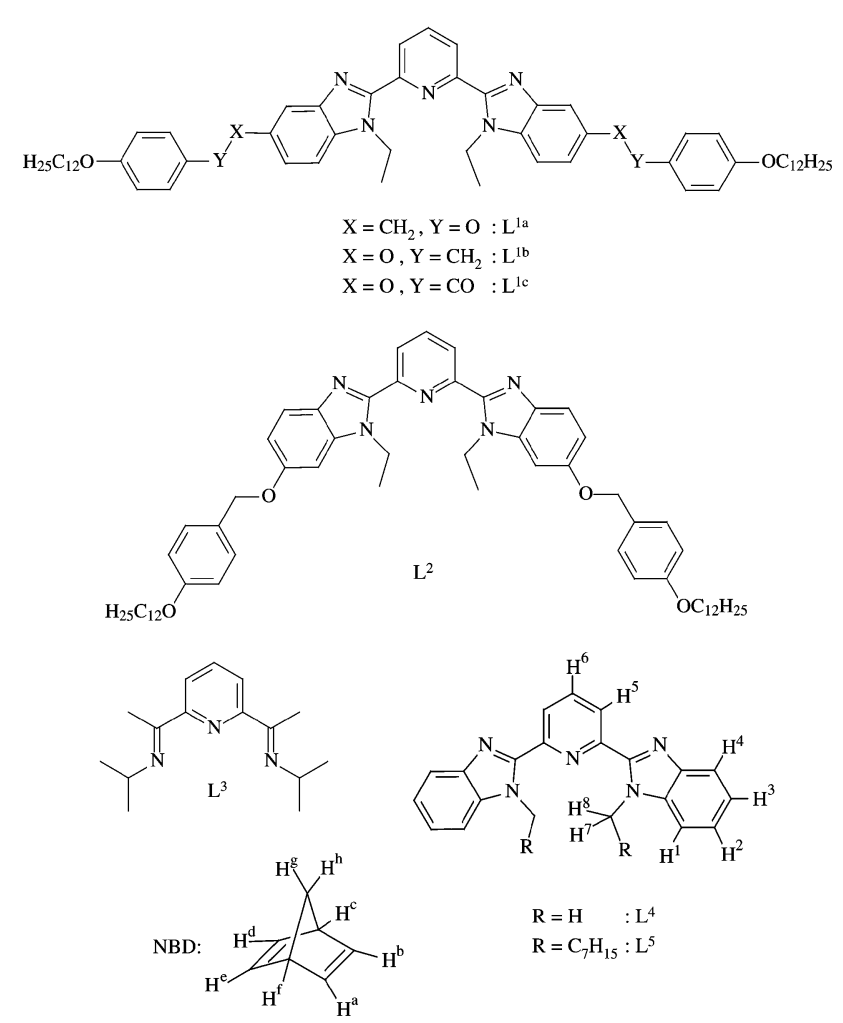

Scheme 1

and $\mathrm{Ln}\left(\mathrm{CF}_{3} \mathrm{CO}_{2}\right)_{3}(\mathrm{Ln}=\mathrm{La}$ to $\mathrm{Lu})$ provides non-mesogenic rod-like $\left[\mathrm{Ln}\left(\mathrm{L}^{2}\right)\left(\mathrm{NO}_{3}\right)_{3}\right]$ and $\left[\mathrm{Ln}\left(\mathrm{L}^{2}\right)\left(\mathrm{CF}_{3} \mathrm{CO}_{2}\right)_{3}\right]_{2}$ and $\mathrm{U}$-shaped $\left[\mathrm{Ln}\left(\mathrm{L}^{1}\right)\left(\mathrm{NO}_{3}\right)_{3}\right]$ complexes. ${ }^{8,9}$ We tentatively assign this dramatic 
change to the large spatial expansion induced by co-ordination of anions and/or solvent molecules on both sides of the plane defined by the meridionally three-co-ordinated binding unit and the metal ion in the complexes. In order to test the potential use of $\mathrm{L}^{1}$ and $\mathrm{L}^{2}$ for producing calamitic metallomesogens, we have launched into a research project aiming at introducing metal ions and counter anions producing controlled anisometry and predictable steric characteristics in the final complexes. Although five-co-ordinated and tetrahedral complexes with $\mathrm{Rh}^{\mathrm{I}}$ have been reported, ${ }^{11}$ the strong stereochemical preference of $\mathrm{Rh}^{\mathrm{I}}$ for square-planar complexes ${ }^{11,12}$ together with its single positive charge are compatible with the design of neutral square-planar complexes in which $\mathrm{Rh}^{\mathrm{I}}$ is meridionally three-coordinated by a neutral terdentate chelating nitrogen ligand, the fourth position being occupied by a co-ordinating anion $\left(\mathrm{Cl}^{-}\right.$, $\left.\mathrm{Br}^{-}\right)$. Contrary to the rich literature reporting rhodium(I) complexes with $\pi$-acid ligands, ${ }^{11}$ the complexation of $\mathrm{Rh}^{\mathrm{I}}$ with terdentate aromatic $\mathrm{N}$-donor ligands has poorly been explored and we are aware of a single report describing the structure of the highly reactive complex $\left[\mathrm{Rh}\left(\mathrm{L}^{3}\right) \mathrm{Cl}\right]$ in which $\mathrm{Rh}^{\mathrm{I}}$ is meridionally three-co-ordinated by a complexing unit analogous to that found in $\mathrm{L}^{i}(i=1$ or 2$) .{ }^{13}$ Detailed studies of this complex in solution show that (i) complicated intra- and intermolecular exchange processes involve the imine side arms on the NMR timescale at room temperature and (ii) only weakly bound alkenes can be replaced by the nitrogen atoms of $\mathrm{L}^{3} .^{14}$ To the best of our knowledge, no study involving $2,2^{\prime}: 6^{\prime}, 2^{\prime \prime}$ terpyridine (terpy) or its derivatives has been reported and this paper describes the complexation behaviour of $\mathrm{Rh}^{\mathrm{I}}$ with the analogous ligands 2,6-bis(1-alkylbenzimidazol-2-yl)pyridine $\mathrm{L}^{4}$ and $L^{5}$ which are (i) slightly better $\pi$-accepting ligands compared with terpy ${ }^{15}$ and (ii) considered as simple models of the co-ordination sites found in $\mathrm{L}^{1}$ and $\mathrm{L}^{2}$.

\section{Results and discussion}

\section{Structure of ligands $L^{4}$ and $L^{5}$}

Theoretical calculations using semi-empirical EHMO ${ }^{16}$ and ZINDO (INDO/S developed by Zerner) ${ }^{9}$ methods suggest that the trans-trans conformation (i.e. the nitrogen atom of the pyridine ring is trans to the unsubstituted nitrogen atoms of the benzimidazole rings) corresponds to the most stable geometry in the gas phase and in solution as demonstrated by the predicted electronic spectra which closely match those recorded in acetonitrile-dichloromethane. ${ }^{1} \mathrm{H}$ NMR studies of $\mathrm{L}^{1}, \mathrm{~L}^{2}, \mathrm{~L}^{4}$ and $\mathrm{L}^{5}$ confirm that the ligands display an average $C_{2 \mathrm{v}}$ symmetry in solution in agreement with a trans-trans conformation on the NMR timescale which is ascertained by the lack of NOE effects between $\mathrm{H}^{7,8}$ and $\mathrm{H}^{5} .{ }^{8,9,16}$ Finally, crystal structures of $\mathrm{L}^{1 \mathrm{a}}$ and $\mathrm{L}^{1 \mathrm{~b}}$ unambiguously establish that approximate transtrans conformations are also adopted in the solid state, ${ }^{8}$ but severe distortions occur when one benzimidazole side arm is protonated in $\left[\mathrm{L}^{4}+\mathrm{H}\right] \mathrm{ClO}_{4}{ }^{17}$ In order to assess the relative and subtle effects of (i) protonation, (ii) crystal packing forces and (iii) steric constraints induced by the substituents borne by the benzimidazole rings on the exact conformation of the terdentate core, we have solved the crystal structure of $\mathrm{L}^{4}$. Fig. 1 shows the atomic numbering scheme and Fig. 2 a comparison of the molecular structures of $\mathrm{L}^{4}$ and $\left[\mathrm{L}^{4}+\mathrm{H}\right]^{+}$. Selected bond distances and bond angles are given in the ESI supporting information (Table $\mathrm{S} 1$ ).

The molecular structure of $\mathrm{L}^{4}$ in the solid state confirms the approximate trans-trans conformation of the bis(benzimidazolyl)pyridine binding unit (N1 is trans with respect to $\mathrm{N} 2$ and $\mathrm{N} 4$ ), and the $\mathrm{C}-\mathrm{C}$ and $\mathrm{C}-\mathrm{N}$ bond distances and bond angles are within standard values ${ }^{18}$ in complete agreement with those found in $\mathrm{L}^{1 \mathrm{a}}, \mathrm{L}^{2 \mathrm{a}}$ and $\left[\mathrm{L}^{4}+\mathrm{H}\right]^{+}$. The only significant differences between the conformations of these terdentate binding units result from variable interplanar angles between the connected

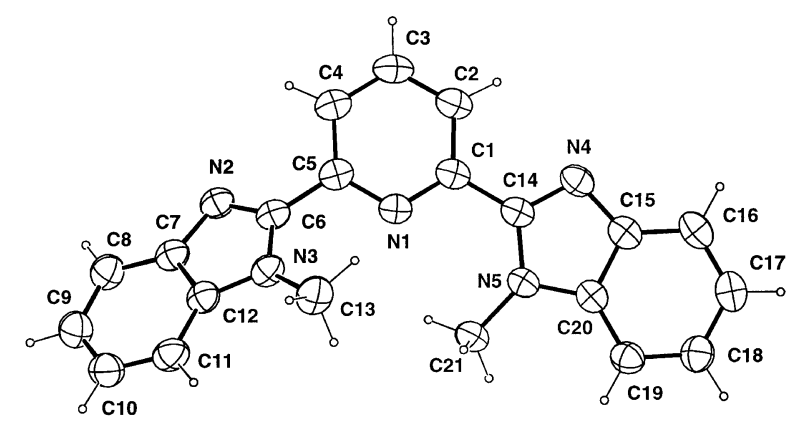

Fig. 1 Numbering scheme for the ligand $\mathrm{L}^{4}$. Ellipsoids are represented at the $50 \%$ probability level.

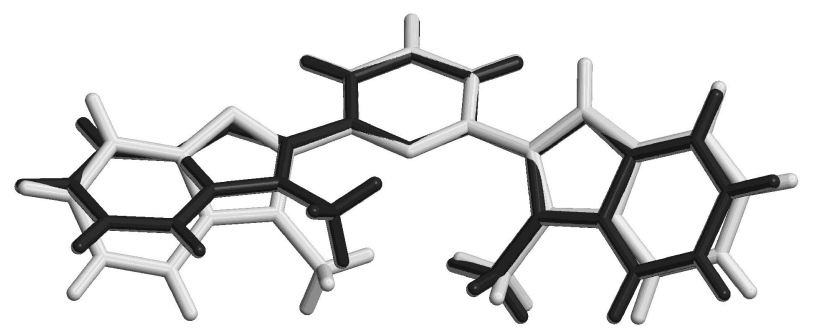

Fig. 2 Superimposed representation of the molecular structures of $\mathrm{L}^{4}$ (black) and $\left[\mathrm{L}^{4}+\mathrm{H}\right]^{+}$(grey). ${ }^{17}$

pyridine and benzimidazole units. In $\mathrm{L}^{4}$ the benzimidazole ring $\mathrm{N} 4, \mathrm{~N} 5$ is almost coplanar with the pyridine ring (interplanar angle: $\left.7.11(3)^{\circ}\right)$, while a larger torsion $\left(36.80(3)^{\circ}\right)$ is observed between the pyridine ring and the second benzimidazole side arm $(\mathrm{N} 2, \mathrm{~N} 3)$. Similar geometries are observed for $\mathrm{L}^{1 \mathrm{a}}$ (interplanar angles: $\left.3.2^{\circ}, 20.9^{\circ}\right)^{8}$ and $\mathrm{L}^{1 \mathrm{~b}}$ (interplanar angles: $12.3^{\circ}$, $\left.35.6^{\circ}\right){ }^{8}$ while a larger distortion from planarity characterises the arrangement of the aromatic rings in $\left[\mathrm{L}^{4}+\mathrm{H}\right]^{+}$(interplanar angles: $30.5,45.3^{\circ}$, Fig. 2). ${ }^{17}$ This strongly suggests that (i) the increased steric constraints when going from $N$-methyl- $\left(\mathrm{L}^{4}\right)$ to $N$-ethyl-benzimidazole rings $\left(\mathrm{L}^{1 \mathrm{a}}, \mathrm{L}^{1 \mathrm{~b}}\right)$ have only minor effects on the conformation of the tridentate core and (ii) intermolecular interactions (dipolar, hydrogen bonds, $\pi$ stacking) mainly control the fine arrangement of the terdentate core in the solid state. These hypotheses are supported by the contact distances between the carbon atoms of the alkyl substituents directly connected to the benzimidazole rings $(\mathrm{C} 13 \cdots \mathrm{C} 21$ for $\mathrm{L}^{4}$ ) which display no straightforward relationship with the nature of the substituents $\left(3.81\left(\mathrm{~L}^{4}\right), 3.75\left(\mathrm{~L}^{1 \mathrm{a}}\right), 3.94\left(\mathrm{~L}^{1 \mathrm{~b}}\right)\right.$ and $\left.3.61 \AA\left(\left[\mathrm{L}^{4}+\mathrm{H}\right]^{+}\right)\right)$, but which depend on specific intermolecular interactions. In $\mathrm{L}^{4}$ and $\mathrm{L}^{1 a}$ the almost coplanar pyridine-benzimidazole moieties of one ligand strongly interact with the identical moiety of a second molecule related by an inversion centre $(1-x, 1-y, 1-z)$, thus producing headto-head $\pi$-stacked pairs whose average interplanar distance (3.41(7) for $\mathrm{L}^{4}, 3.50 \AA$ for $\mathrm{L}^{1 \mathrm{a}},{ }^{8} \mathrm{ESI}$ Fig. S1) can be compared to that found in graphite $(3.35 \AA) .{ }^{19} \mathrm{In} \mathrm{L}^{1 \mathrm{~b}}$ the terdentate core is not involved in significant intermolecular stacking interactions ${ }^{8}$ and a complicated network of hydrogen bonds involving the protonated benzimidazole ring controls the packing in $\left[\mathrm{L}^{4}+\mathrm{H}\right] \mathrm{ClO}_{4} \cdot{ }^{17}$

\section{Synthesis and characterisation of the complexes}

Attempts to use $\left[\mathrm{Rh}\left(\mathrm{C}_{2} \mathrm{H}_{4}\right)_{2} \mathrm{Cl}\right]_{2}$ containing weakly bound alkenes as starting material ${ }^{20}$ produce intricate mixtures of fluxional complexes with $\mathrm{L}^{4}$ or $\mathrm{L}^{5}$ on the NMR timescale between 210 and $333 \mathrm{~K}$ in $\mathrm{CDCl}_{3}$. Reactions in DMSO-d ${ }^{6}$ show the appearance of solvated ethylene in agreement with its low affinity for $\mathrm{Rh}^{\mathrm{I}},{ }^{14}$ but we were not able to isolate pure complexes in solution or in the solid state. Reaction of $\mathrm{L}^{4}(1.0$ equivalent) with the alternative starting complex $[\mathrm{Rh}(\mathrm{NBD})-$ $\mathrm{Cl}_{2}$ (1.0 equivalent; NBD $=$ bicyclo[2.2.1] hepta-2,5-diene) in 
dichloromethane produces a yellow precipitate which is insoluble in most organic and inorganic solvents. The IR spectrum displays absorption bands in the $1200-1600 \mathrm{~cm}^{-1}$ domain typical of the terdentate ligand $\left(1460,1560,1580 \mathrm{~cm}^{-1}\right.$; $v(\mathrm{C}=\mathrm{C})+v(\mathrm{C}=\mathrm{N}))$ and of the co-ordinated norbornadiene (NBD) fragment $\left(1375 \mathrm{~cm}^{-1} ; v(\mathrm{C}=\mathrm{C})\right)$. Elemental analyses are compatible with the formulation $\left[\{\mathrm{Rh}(\mathrm{NBD}) \mathrm{Cl}\}_{2} \mathrm{~L}^{4}\right] \cdot 3 \mathrm{H}_{2} \mathrm{O} \mathbf{1}$ in agreement with the formation of a dimetallic complex. Positive mode ESI-MS spectra recorded for a highly diluted solution of 1 in THF show only two peaks corresponding to $\left[\mathrm{Rh}_{2}(\mathrm{NBD})_{2}-\right.$ $\left.\mathrm{Cl}\left(\mathrm{L}^{4}\right)\right]^{+}(m / z=764.2)$ and $\left[\mathrm{Rh}(\mathrm{NBD})\left(\mathrm{L}^{4}\right)\right]^{+}(m / z=534.2)$ and MS-MS experiments demonstrate that $\left[\mathrm{Rh}_{2}(\mathrm{NBD})_{2} \mathrm{Cl}\left(\mathrm{L}^{4}\right)\right]^{+}$ fragments to give $\left[\mathrm{Rh}(\mathrm{NBD})\left(\mathrm{L}^{4}\right)\right]^{+}$with concomitant loss of one $[\mathrm{Rh}(\mathrm{NBD}) \mathrm{Cl}]$ unit. We thus conclude that the charged complex $\left[\mathrm{Rh}_{2}(\mathrm{NBD})_{2} \mathrm{Cl}\left(\mathrm{L}^{4}\right)\right]^{+}$observed in the gas phase originates from dissociation of chloride from the neutral dimetallic precursor $\left[\left\{\mathrm{Rh}(\mathrm{NBD}) \mathrm{Cl}_{2_{2}} \mathrm{~L}^{4}\right]\right.$. Unfortunately, we were unable to obtain X-ray quality crystals of $\mathbf{1}$ as a result of its poor solubility and have repeated these experiments with the lipophilic analogue $\mathrm{L}^{5}$. Reaction of $\mathrm{L}^{5}$ with $[\mathrm{Rh}(\mathrm{NBD}) \mathrm{Cl}]_{2}$ in acetonitrile for stoichiometric ratios $1: 1$ or $2: 1$ gives good yields (calculated for the limiting reactant) of a microcrystalline yellow powder. The elemental analyses, IR and ESI-MS spectra $\left(\left[\mathrm{Rh}_{2}(\mathrm{NBD})_{2} \mathrm{Cl}\left(\mathrm{L}^{5}\right)\right]^{+} \quad(m / z=960.1)\right.$ and $\left[\mathrm{Rh}(\mathrm{NBD})\left(\mathrm{L}^{5}\right)\right]^{+}$ $(m / z=730.3))$ are compatible with the formulation as a dimetallic complex $\left[\left\{\mathrm{Rh}(\mathrm{NBD}) \mathrm{Cl}_{\}_{2}} \mathrm{~L}^{5}\right] \mathbf{2}\right.$ which is more soluble in organic solvent than $\mathbf{1}$. Recrystallisation from hot acetonitrile provides crystals suitable for X-ray diffraction studies.

\section{Crystal and molecular structure of $\left[\left\{\mathrm{Rh}(\mathrm{NBD}) \mathrm{Cl}_{{ }_{2}} \mathrm{~L}^{5}\right] 2\right.$}

The molecular structure of $\mathbf{2}$ consists of a dimetallic complex in which $\mathrm{L}^{5}$ acts as a bis-monodentate bridging ligand, one

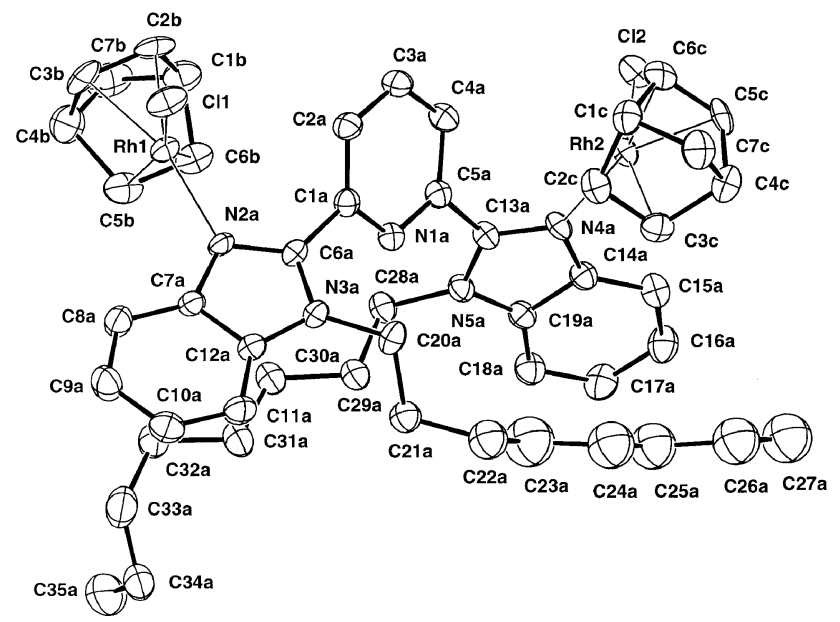

Fig. 3 Numbering scheme for the complex $\left[\left\{\mathrm{Rh}(\mathrm{NBD}) \mathrm{Cl}_{2} \mathrm{~L}^{5}\right] 2\right.$ Ellipsoids are represented at the $40 \%$ probability level. nitrogen atom of each benzimidazole ring being co-ordinated to a $[\mathrm{Rh}(\mathrm{NBD}) \mathrm{Cl}]$ unit. Selected bond distances and bond angles are collected in Table 1; Fig. 3 displays the atomic numbering scheme and a stereoview of the complex is shown in Fig. 4.

The terdentate core of the complex adopts a distorted trans-trans conformation similar to that found in the molecular structure of the ligand $\mathrm{L}^{4}$, but it evidences larger interplanar angles between the non-co-ordinating central pyridine ring and the benzimidazole side arms (48.58(3) and 55.25(3) ${ }^{\circ}$, ESI Table S2), thus producing a significant helical twist of $\mathrm{L}^{5}$. The contact distance between the carbon atoms bound to the benzimidazole rings C20a $\cdots$ C28a 5.412(6) $\AA$ is significantly larger than those found in $\mathrm{L}^{1 \mathrm{a}}, \mathrm{L}^{1 \mathrm{~b}}, \mathrm{~L}^{4}$ and $\left[\mathrm{L}^{4}+\mathrm{H}\right]^{+}$which strongly suggests that only minor repulsion occurs between the divergent lipophilic octyl chains. Each rhodium atom is fourco-ordinated by one nitrogen atom of a benzimidazole ring, one chloride and one chelating norbornadiene. The latter diene is considered as a bidentate ligand with the double bonds connected through their midpoints to the rhodium atom (Table 1, Fig. 3). The two resulting distorted square-planar metallic co-ordination spheres are very similar with $\mathrm{Rh}^{\mathrm{I}}$ located slightly out of the plane of the four-co-ordinating centres (deviation: 0.057(1) $\AA$ for $\mathrm{Rh} 1$ and 0.011(1) $\AA$ for Rh2). The $\mathrm{Rh}-\mathrm{Cl}$ distances (2.360-2.366 $\AA$, Table 1) are standard ${ }^{22}$ and can be compared to $2.3488(5) \AA$ found in $\left[\mathrm{Rh}\left(\mathrm{L}^{3}\right) \mathrm{Cl}\right] .{ }^{13} \mathrm{The} \mathrm{Rh}-\mathrm{C}$ distances $(2.102-2.124 \AA$, average $2.11(1) \AA)$ are slightly shorter than those found in other rhodium complexes containing NBD or 1,5-cyclooctadiene $(2.156 \AA)$, but they are close to those observed in rhodium complexes with ethylene $(2.129 \AA) .{ }^{22}$ The $\mathrm{Rh}-\mathrm{N}$ distances $(2.110-2.113 \AA)$ are also standard ${ }^{22}$

Table 1 Selected bond distances $(\AA)$ and angles $\left({ }^{\circ}\right)$ for $[\{\mathrm{Rh}(\mathrm{NBD})$ $\left.\mathrm{Cl}\}_{2} \mathrm{~L}^{5}\right] 2$

\begin{tabular}{|c|c|c|c|}
\hline Rh1 $\cdots$ Rh2 & $8.4218(6)$ & & \\
\hline Rh1-Cl1 & $2.366(1)$ & $\mathrm{Rh} 2-\mathrm{Cl} 2$ & $2.360(1)$ \\
\hline $\mathrm{Rh} 1-\mathrm{N} 2 \mathrm{a}$ & $2.113(4)$ & $\mathrm{Rh} 2-\mathrm{N} 4 \mathrm{a}$ & $2.110(3)$ \\
\hline $\mathrm{Rh} 1-\mathrm{C} 2 \mathrm{~b}$ & $2.118(5)$ & $\mathrm{Rh} 2-\mathrm{C} 2 \mathrm{c}$ & $2.106(5)$ \\
\hline $\mathrm{Rh} 1-\mathrm{C} 3 \mathrm{~b}$ & $2.124(6)$ & $\mathrm{Rh} 2-\mathrm{C} 3 \mathrm{c}$ & $2.116(5)$ \\
\hline $\mathrm{Rh} 1-\mathrm{P} 1 \mathrm{~b}^{a}$ & $2.0051(4)$ & $\mathrm{Rh} 2-\mathrm{P} 1 \mathrm{c}^{a}$ & $1.9922(3)$ \\
\hline Rh1-C5b & $2.108(6)$ & $\mathrm{Rh} 2-\mathrm{C} 5 \mathrm{c}$ & $2.118(4)$ \\
\hline Rh1-C6b & $2.102(5)$ & Rh2-C6c & $2.121(5)$ \\
\hline $\mathrm{Rh} 1-\mathrm{P} 2 \mathrm{~b}^{a}$ & $1.9876(4)$ & $\mathrm{Rh} 2-\mathrm{P} 2 \mathrm{c}^{a}$ & $2.0010(3)$ \\
\hline N2a-Rh1-Cl1 & $88.2(1)$ & $\mathrm{N} 4 \mathrm{a}-\mathrm{Rh} 2-\mathrm{Cl} 2$ & $90.75(9)$ \\
\hline $\mathrm{N} 2 \mathrm{a}-\mathrm{Rh} 1-\mathrm{P} 1 \mathrm{~b}^{a}$ & $172.0(1)$ & $\mathrm{N} 4 \mathrm{a}-\mathrm{Rh} 2-\mathrm{P} 1 \mathrm{c}^{a}$ & $99.42(9)$ \\
\hline $\mathrm{N} 2 \mathrm{a}-\mathrm{Rh} 1-\mathrm{P} 2 \mathrm{~b}^{a}$ & $100.9(1)$ & $\mathrm{N} 4 \mathrm{a}-\mathrm{Rh} 2-\mathrm{P} 2 \mathrm{c}^{a}$ & 171.1(1) \\
\hline $\mathrm{Cl1}-\mathrm{Rh} 1-\mathrm{P} \mathrm{b}^{a}$ & $98.55(4)$ & $\mathrm{Cl} 2-\mathrm{Rh} 2-\mathrm{P} 1 \mathrm{c}^{a}$ & $169.76(3)$ \\
\hline $\mathrm{Cl1}-\mathrm{Rh} 1-\mathrm{P} 2 \mathrm{~b}^{a}$ & $170.56(4)$ & $\mathrm{Cl} 2-\mathrm{Rh} 2-\mathrm{P} 2 \mathrm{c}^{a}$ & $97.79(3)$ \\
\hline $\mathrm{P} 1 \mathrm{~b}-\mathrm{Rh} 1-\mathrm{P} 2 \mathrm{~b}^{a}$ & $72.15(1)$ & $\mathrm{P} 1 \mathrm{c}-\mathrm{Rh} 2-\mathrm{P} 2 \mathrm{c}^{a}$ & $72.11(1)$ \\
\hline
\end{tabular}

${ }^{a} \mathrm{P} 1 i$ is the midpoint between the carbon atoms $\mathrm{C} 2 i$ and $\mathrm{C} 3 i$ and $\mathrm{P} 2 i$ that between $\mathrm{C} 5 i$ and $\mathrm{C} 6 i(i=\mathrm{b}$ or $\mathrm{c})$; the uncertainties of $P_{j i}$ are set to 0 ( $j=1$ or 2 and $i=\mathrm{b}$ or $\mathrm{c}$ ).
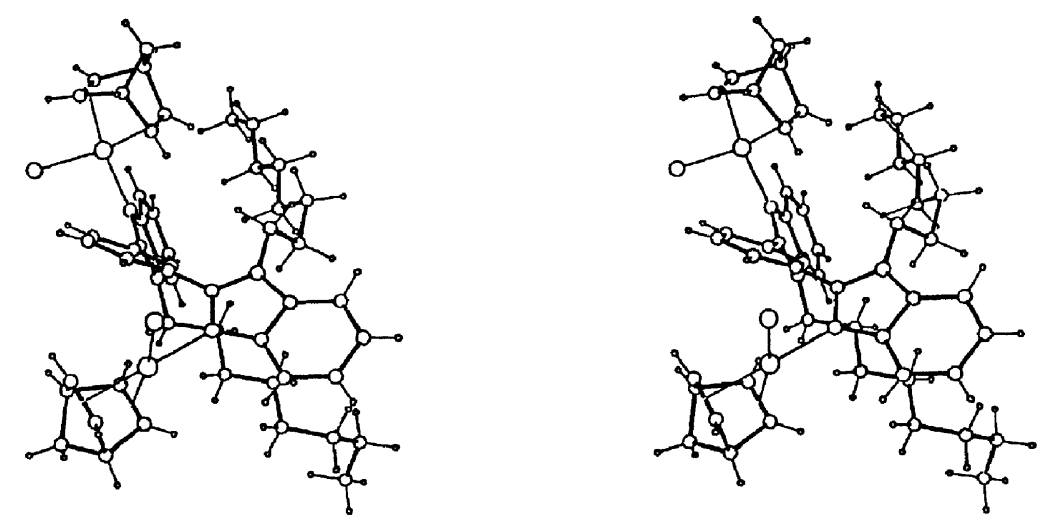

Fig. 4 ORTEP ${ }^{21}$ stereoview of complex 2 along the helically twisted terdentate binding unit. 
and similar to that found in $[\mathrm{Rh}(\mathrm{NBD}) \mathrm{Cl}(\mathrm{dmap})](2.106 \AA$; dmap $=4-(N, N$-dimethylamino)pyridine $){ }^{23}$ The pseudosquare-planar units [Rh1, N2a, Cl1, P1b, P2b] and [Rh2, N4a, $\mathrm{Cl} 2, \mathrm{P} 1 \mathrm{c}, \mathrm{P} 2 \mathrm{c}]$ adopt almost orthogonal arrangements with respect to the benzimidazole ring to which they are connected $\left(81.14(3)^{\circ}\right.$ for $\mathrm{Rh} 1$ and $77.23(3)^{\circ}$ for $\left.\mathrm{Rh} 2\right)$ together with a relative antiparallel orientation of the $\mathrm{Rh} 1-\mathrm{Cl} 1$ and $\mathrm{Rh} 2-\mathrm{Cl} 2$ vectors located respectively above and below the least-square plane passing through the twisted terdentate bridging ligand (Fig. 4). Although no crystallographic symmetry is observed for the dimetallic complex $\left[\{\mathrm{Rh}(\mathrm{NBD}) \mathrm{Cl}\}_{2} \mathrm{~L}^{5}\right]$, the non-aliphatic part of the structure shows a pseudo- $C_{2}$ axis passing through $\mathrm{N} 1 \mathrm{a}$ and $\mathrm{C} 3 \mathrm{a}$. The observed and refined olefinic hydrogen atoms of the NBD units severely deviate $(0.18-0.31 \AA$, average $0.25(5) \AA$ ) from their expected positions in pure $\mathrm{sp}^{2}$ hybrids consistent with steric constraints and/or efficient $\mathrm{Rh} \rightarrow \mathrm{NBD}$ $\pi$-back-donation which move these hydrogen atoms away from the rhodium metal. Finally, weak $\pi$-stacking interactions between the parallel benzimidazole rings N4a, N5a of two complexes related by an inversion centre (average stacking dis-
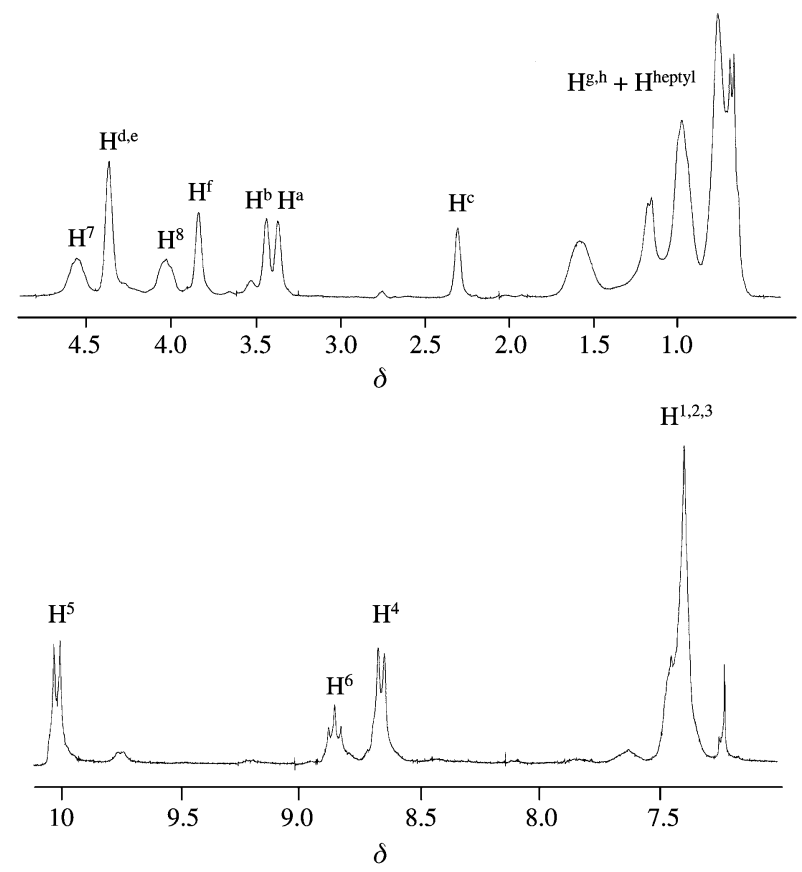

Fig. $5{ }^{1} \mathrm{H}$ NMR spectrum of complex 2 in $\mathrm{CDCl}_{3}$ at $210 \mathrm{~K}$.

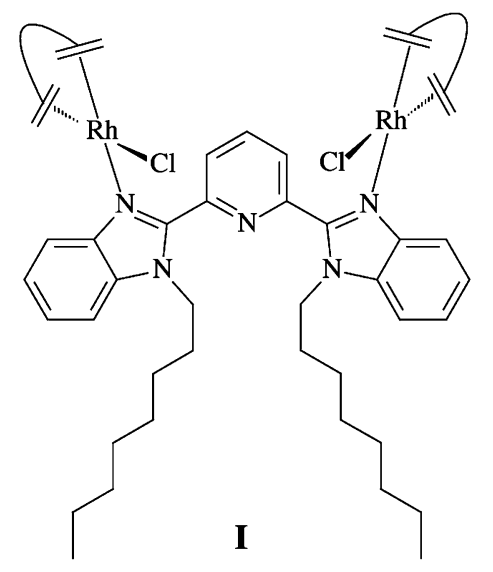

tance: $3.559(8) \AA$ ) produce associations by pairs in the crystal packing of 2 (ESI Fig. S2).

\section{Solution structure of $\left[\left\{\mathrm{Rh}(\mathrm{NBD}) \mathrm{Cl}_{2} \mathrm{~L}^{5}\right] 2\right.$}

The ${ }^{1} \mathrm{H}$ NMR spectra of complex 2 in $\mathrm{CDCl}_{3}$ or $\mathrm{CD}_{2} \mathrm{Cl}_{2}$ at room temperature display only broad signals resulting from slow intra- and/or inter-molecular exchange processes as previously observed for related rhodium complexes with bidentate and terdentate nitrogen ligands. ${ }^{13,14}$ At low temperature $(210 \mathrm{~K})$ a series of resolved signals corresponding to a single species in slow exchange on the NMR timescale $(>90 \%$ of the ligand speciation according to the integration of the signals) can be assigned by using $\left\{{ }^{1} \mathrm{H}-{ }^{1} \mathrm{H}\right\}-\mathrm{COSY}$ spectra and NOE measurements (Fig. 5). The $\mathrm{AX}_{2}$ spin system observed for the protons $\mathrm{H}^{5,6}$, together with the equivalence of the two benzimidazole side arms, point to the existence of a symmetry element (a mirror plane or a twofold axis) bisecting the central pyridine ring. The $1: 2$ ratio of the integrals of the signals for protons belonging to $\mathrm{L}^{5}$ and NBD respectively indicates that the dimetallic structure found in the solid state is maintained in solution and the considerable complexation shifts observed for $\mathrm{H}^{5}(\Delta \delta=1.70 \mathrm{ppm})$ and $\mathrm{H}^{4}(\Delta \delta=0.81 \mathrm{ppm})$ confirm the co-ordination of the benzimidazole rings to [Rh(NBD)Cl]. The observation of two multiplets for the diastereotopic protons $\mathrm{H}^{7,8}$ precludes the existence of an average mirror plane containing the terdentate binding unit on the NMR timescale and the concomitant non-equivalence of $\mathrm{H}^{\mathrm{a}, \mathrm{b}, \mathrm{d}, \mathrm{e}}$ and $\mathrm{H}^{\mathrm{c}, \mathrm{f}}$ implies that (i) the co-ordinated norbornadienes do not rotate rapidly on the NMR timescale and (ii) the perpendicular orientation of the square-planar rhodium units with respect to the benzimidazole rings is maintained in solution. We thus conclude that the dimetallic complex adopts an average $C_{\mathrm{s}^{-}}$(I) or $C_{2}$-symmetrical structure (II) in solution at low temperature (Fig. 6). The latter arrangement (II) is closer to that found in the solid state, but NMR spectra cannot distinguish between these two structures. Finally, it is worth noting that the detected intramolecular $\mathrm{NOE}$ effects are systematically negative for 2 in $\mathrm{CDCl}_{3}$ at $210 \mathrm{~K}$ consistent with a slow tumbling rate of the complex. ${ }^{24} \mathrm{We}$ tentatively assign this effect to the increased viscosity of the solvent (freezing point of $\mathrm{CHCl}_{3}: 209 \mathrm{~K}$ ) and this is supported by the detection of related, but weakly positive NOE effects for 2 in $\mathrm{CD}_{2} \mathrm{Cl}_{2}$ at $210 \mathrm{~K}$ (freezing point of $\mathrm{CH}_{2} \mathrm{Cl}_{2}: 178 \mathrm{~K}$ ).

\section{Conclusion}

The reactions of the potentially terdentate binding units $\mathrm{L}^{4}$ and $\mathrm{L}^{5}$ with $[\mathrm{Rh}(\mathrm{NBD}) \mathrm{Cl}]_{2}$ produce exclusively the dimetallic

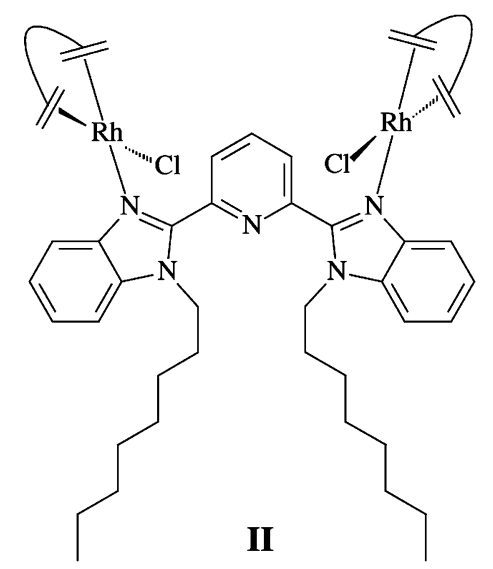<smiles>C=CCC(=C)C([NH3+])=O</smiles>

Fig. 6 Possible structures for complex 2 in solution at $210 \mathrm{~K}$. 
complexes $\left[\{\mathrm{Rh}(\mathrm{NBD}) \mathrm{Cl}\}_{2} \mathrm{~L}^{i}\right](i=4$ or 5$)$ in which $\mathrm{L}^{4}$ and $\mathrm{L}^{5}$ act as bis-monodentate bridging ligands as previously reported for the double-stranded helicates $\left[\mathrm{M}_{2}\left(\mathrm{~L}^{4}\right)_{2}\right]^{2+}\left(\mathrm{M}=\mathrm{Cu}^{\mathrm{I}}\right.$ or $\left.\mathrm{Ag}^{\mathrm{I}}\right) .^{25,26}$ In the latter complexes the metal ions are essentially linearly coordinated by two benzimidazole units belonging to the different strands and theoretical calculations ${ }^{25}$ suggest that the doublestranded helical structure results from a compromise between specific steric constraints and the electronic destabilisation of the alternative monometallic Y-shaped complexes. ${ }^{26}$ For the larger $\mathrm{Rh}^{\mathrm{I}}$ a less constrained $\mathrm{T}$-shaped geometry is required for a monometallic complex with $\mathrm{L}^{i}(i=4$ or 5$)$ and the latter argument is no longer valid since a related arrangement has been observed in $\left[\mathrm{Rh}\left(\mathrm{L}^{3}\right) \mathrm{Cl}\right]{ }^{13}$ We thus tentatively assign the absence of double-stranded helical structures as a result of the weak $\pi$-accepting properties of the ligands $\mathrm{L}^{4}$ and $\mathrm{L}^{5}$ which cannot stabilise the electron-rich $\mathrm{Rh}^{\mathrm{I}}$ in a two-co-ordinate linear arrangement. Moreover, $\mathrm{L}^{4}$ and $\mathrm{L}^{5}$ are unable to displace the chelated norbornadiene which precludes meridional threeco-ordination around $\mathrm{Rh}^{\mathrm{I}}$, a complexation mode found for numerous complexes between $\mathrm{L}^{4}$ and $\mathrm{M}^{\mathrm{II}}(\mathrm{M}=\mathrm{Mn}, \mathrm{Fe}, \mathrm{Co}, \mathrm{Cu}$, $\mathrm{Zn}, \mathrm{Ru}$ or $\mathrm{Pt})^{15,27}$ and $\mathrm{M}^{\mathrm{III}}\left(\mathrm{M}=\mathrm{Co}^{28}\right.$ or $\left.\mathrm{Ln}^{29}\right)$. We conclude that the observed dimetallic complexes $\mathbf{1}$ and $\mathbf{2}$ correspond to a compromise in which $\mathrm{Rh}^{\mathrm{I}}$ is tetragonally co-ordinated by a chelating $\pi$-accepting diene, a chloride anion and a nitrogen donor consistent with its stereoelectronic requirements. However, the resulting large spatial expansion brought by the [Rh(NBD)Cl] units co-ordinated to the terdentate core strongly limits the preparation of extended rod-like complexes with $\mathrm{L}^{2}$ possessing minimal perpendicular anisometries compatible with calamitic mesomorphism. The alternative meridional co-ordination observed with square-planar $\mathrm{Pd}^{\mathrm{II}}$ or $\mathrm{Pt}^{\mathrm{II}}$ might overcome this limitation, but the increased positive charge borne by the metal is better suited for the preparation of amphiphilic aggregates such as Langmuir-Blodgett films or lyotropic metallomesogens. ${ }^{27}$ Finally, $\mathrm{Rh}^{\mathrm{I}}$-diene complexes bearing amine ligands are regarded as convenient precursors of various organorhodium complexes which can be used as catalysts for the efficient polymerisation of alkynes. ${ }^{30}$

\section{Experimental}

\section{Solvents and starting materials}

These were purchased from Fluka AG (Buchs, Switzerland) and used without further purification unless otherwise stated. The ligands $\mathrm{L}^{4}$ and $\mathrm{L}^{5}$ were prepared according to literature procedures. ${ }^{15} \mathrm{X}$-Ray quality crystals of $\mathrm{L}^{4}$ were obtained by recrystallisation from dimethyl sulfoxide-acetonitrile. Hexane, dichloromethane and acetonitrile were distilled from $\mathrm{CaH}_{2}$ and all experiments were carried out in a dry nitrogen atmosphere using standard Schlenk techniques.

\section{Preparations}

$\left[\left\{\mathbf{R h}(\mathbf{N B D}) \mathbf{C l}_{2} \mathbf{L}^{4}\right] \cdot \mathbf{3} \mathbf{H}_{\mathbf{2}} \mathbf{O} \mathbf{1 .} 40 \mathrm{mg} \mathrm{L} \mathrm{L}^{4}(0.12 \mathrm{mmol})\right.$ in a dry dichloromethane solution $\left(20 \mathrm{~cm}^{3}\right)$ were added under nitrogen to a dichloromethane solution $\left(10 \mathrm{~cm}^{3}\right)$ of $[\mathrm{Rh}(\mathrm{NBD}) \mathrm{Cl}]_{2}$ $(54.5 \mathrm{mg}, 0.12 \mathrm{mmol})$. The resulting solution was stirred for $30 \mathrm{~min}$ and the yellow precipitate was filtered off, washed with hexane $\left(20 \mathrm{~cm}^{3}\right)$ and dried in vacuum to give $80 \%$ of [ $\{\mathrm{Rh}-$ (NBD)Cl $\left.\}_{2} \mathrm{~L}^{4}\right] \cdot 3 \mathrm{H}_{2} \mathrm{O} 1(75 \mathrm{mg}, 0.096 \mathrm{mmol})$. Calc. for $\mathrm{C}_{49} \mathrm{H}_{55}$ $\mathrm{Cl}_{2} \mathrm{~N}_{5} \mathrm{O}_{3} \mathrm{Rh}_{2}$ : C, 49.20; N, 8.20; H, 4.60. Found: C, 49.38; $\mathrm{N}, 8.22 ; \mathrm{H}, 4.52 \%$. ES-MS (THF): $\mathrm{m} / z$ 764.2 $\left([\mathrm{M}-\mathrm{Cl}]^{+}\right)$and $534.2\left([\mathrm{M}-\mathrm{Cl}-(\mathrm{Rh}(\mathrm{NBD}) \mathrm{Cl})]^{+}\right)$.

[ $\left\{\mathbf{R h}(\mathbf{N B D}) \mathbf{C l}_{\boldsymbol{2}_{2}} \mathbf{L}^{5}\right] \mathbf{2}$. To a solution of $46 \mathrm{mg} \mathrm{L}^{5}(0.086 \mathrm{mmol})$ in acetonitrile $\left(1.5 \mathrm{~cm}^{3}\right), 39.7 \mathrm{mg}$ of $\left[\mathrm{RhCl}\left(\mathrm{C}_{7} \mathrm{H}_{8}\right)\right]_{2}(0.086 \mathrm{mmol})$ in acetonitrile $\left(0.5 \mathrm{~cm}^{3}\right)$ were added dropwise. The reaction was refluxed overnight and the yellow microcrystalline powder was filtered off, washed with hexane $\left(3 \mathrm{~cm}^{3}\right)$ and dried in vacuum. The mother liquor was concentrated, cooled to $4{ }^{\circ} \mathrm{C}$ (1 day) and a second crop of yellow microcrystals collected. The total yield of the resulting complex $\left[\left\{\mathrm{Rh}(\mathrm{NBD}) \mathrm{Cl}_{\}_{2}} \mathrm{~L}^{5}\right] \mathbf{2}\right.$ amounted to $72 \%(62 \mathrm{mg}, 0.062 \mathrm{mmol})$. Suitable crystals for X-ray diffraction studies were obtained by recrystallisation from hot acetonitrile. Calc. for $\mathrm{C}_{49} \mathrm{H}_{61} \mathrm{Cl}_{2} \mathrm{~N}_{5} \mathrm{Rh}_{2}$ : C, 59.04; N, 7.03; $\mathrm{H}$, 6.17. Found: C, 58.66; N, 7.04; H, 6.15\%. ${ }^{1} \mathrm{H}$ NMR in $\mathrm{CDCl}_{3}$ $(210 \mathrm{~K}): \delta 1.13-0.65(32 \mathrm{H}, \mathrm{m}), 2.29(2 \mathrm{H}, \mathrm{s}$, broad $), 3.35(2 \mathrm{H}, \mathrm{s}$, broad), $3.42(2 \mathrm{H}, \mathrm{s}$, broad), $3.83(2 \mathrm{H}, \mathrm{s}$, broad $), 4.02(2 \mathrm{H}, \mathrm{m})$, $4.36(4 \mathrm{H}, \mathrm{s}$, broad), $4.55(2 \mathrm{H}, \mathrm{m}), 7.39(6 \mathrm{H}, \mathrm{m}), 8.65(2 \mathrm{H}, \mathrm{d}$, $\left.{ }^{3} J=8\right), 8.86\left(1 \mathrm{H}, \mathrm{t},{ }^{3} J=8\right)$ and $10.00\left(2 \mathrm{H}, \mathrm{d},{ }^{3} J=8 \mathrm{~Hz}\right)$. ES-MS (THF): $m / z$ 960.1 $\left([\mathrm{M}-\mathrm{Cl}]^{+}\right)$and $730.3([\mathrm{M}-\mathrm{Cl}-(\mathrm{Rh}-$ $(\mathrm{NBD}) \mathrm{Cl})]^{+}$).

These complexes gave IR spectra compatible with their formulations.

\section{Crystal-structure determinations}

$\mathbf{L}^{4} . \mathrm{C}_{21} \mathrm{H}_{17} \mathrm{~N}_{5}, M=339.4$, orthorhombic, space group Pbcn, $a=18.1923(12), b=9.1514(4), c=20.1888(9) \AA, U=3361.1(3)$ $\AA^{3}, Z=8, \mu(\mathrm{Mo}-\mathrm{K} \alpha)=0.08 \mathrm{~mm}^{-1}, T=200 \mathrm{~K}, 39992$ measured reflections, 3308 observed $\left[\left|F_{\mathrm{o}}\right|>4 \sigma\left(F_{\mathrm{o}}\right)\right]$ and 1239 unique $\left(R_{\mathrm{int}}\right.$ for equivalent reflections $=0.061) . R=0.036, w R=0.040$.

[ $\left\{\mathbf{R h}(\mathbf{N B D}) \mathbf{C l}_{\mathbf{}_{2}} \mathbf{L}^{5}\right]$ 2. $\mathrm{C}_{49} \mathrm{H}_{61} \mathrm{Cl}_{2} \mathrm{~N}_{5} \mathrm{Rh}_{2}, M=996.9$, triclinic, space group, $P \overline{1}, a=11.2730(8), b=12.5579(9), c=17.6931(12)$ $\AA, \alpha=92.805(8), \beta=105.964(8), \gamma=103.756(9)^{\circ}, U=2321.5(3)$ $\AA^{3}, Z=2, \mu(\mathrm{Mo}-\mathrm{K} \alpha)=0.86 \mathrm{~mm}^{-1}, T=170 \mathrm{~K}, 22760$ measured reflections, 10428 unique $\left(R_{\text {int }}\right.$ for equivalent reflections $\left.=0.031\right)$ of which 7066 were observed $\left[\left|F_{\mathrm{o}}\right|>4 \sigma\left(F_{\mathrm{o}}\right)\right] . R=0.042, w R=$ 0.044 . The octyl chain $\mathrm{C} 21 \mathrm{a}-\mathrm{C} 27 \mathrm{a}$ was disordered and refined with two atomic sites for each carbon atom with population parameters of 0.5 . The disordered atomic sites were refined with isotropic displacement parameters (14 atoms) and all other non-H atoms (51) with anisotropic displacement parameters.

CCDC reference numbers 152869 and 152870

See http://www.rsc.org/suppdata/dt/b0/b009051o/ for crystallographic data in CIF or other electronic format.

\section{Physical measurements}

IR spectra were obtained from $\mathrm{KBr}$ pellets with a Perkin-Elmer 883 spectrometer, ${ }^{1} \mathrm{H}$ NMR spectra at $25^{\circ} \mathrm{C}$ on a Broadband Varian Gemini 300 spectrometer with chemical shifts given in ppm with respect to TMS. Pneumatically assisted electrospray (ES-MS) mass spectra were recorded from THF solutions on API III or API 3000 tandem mass spectrometers (PE Sciex) by infusion at $4-10 \mu 1 \mathrm{~min}^{-1}$ under low up-front declustering or collision induced dissociation (CID) conditions, typically $\Delta V=0-30 \mathrm{~V}$ between the orifice and the first quadrupole of the spectrometer. Elemental analyses were performed by $\mathrm{Dr}$ $\mathrm{H}$. Eder from the Microchemical Laboratory of the University of Geneva.

\section{Acknowledgements}

This work is supported through grant 4047-057479 from the Swiss National Science Foundation, National Research Programme 47 'Supramolecular Functional Materials'.

\section{References}

1 Metallomesogens, Synthesis, Properties and Applications, ed. J. L. Serrano, VCH, Weinheim, 1996.

2 C. K. Lai, A. G. Serrette and T. M. Swager, J. Am. Chem. Soc., 1992, 114, 7949; A. G. Serrette, C. K. Lai and T. M. Swager, Chem. Mater., 1994, 6, 2252.

3 S. Schmidt, G. Lattermann, R. Kleppinger and J. H. Wendorff, Liq. Cryst., 1994, 16, 693.

4 A. G. Serrete and T. M. Swager, Angew. Chem., Int. Ed. Engl., 1994, 33, 2342.

5 F. Neve, M. Ghedini and A. Crispini, Chem. Commun., 1996, 2463; F. Neve, M. Ghedini, O. Francescangeli and S. Campagna, Liq. Cryst., 1998, 24, 673. 
6 P. Espinet, E. Garcia-Orodea and J. A. Miguel, Inorg. Chem., 2000, 39, 3645 and references therein.

7 D. Shen, A. Pegenau, S. Diele, I. Wirth and C. Tschierske, J. Am Chem. Soc., 2000, 122, 1593; D. Shen, S. Diele, I. Wirth and C. Tschierske, Chem. Commun., 1998, 2573; G. Heppke and D. Moro, Science, 1998, 279, 1872.

8 H. Nozary, C. Piguet, P. Tissot, G. Bernardinelli, J.-C. G. Bünzli, R. Deschenaux and D. Guillon, J. Am. Chem. Soc., 1998, 120, 12274 .

9 H. Nozary, C. Piguet, J.-P. Rivera, P. Tissot, G. Bernardinelli, N. Vulliermet, J. Weber and J.-C. G. Bünzli, Inorg. Chem., 2000, 39, 5286.

10 H. Nozary, C. Piguet, J.-P. Rivera, P. Tissot, R. Deschenaux, B. Donnio, D. Guillon, G. Bernardinelli and J.-C. G. Bünzli, unpublished results.

11 F. A. Cotton and G. Wilkinson, Advanced Inorganic Chemistry, 5th edn., John Wiley \& Sons, New York, 1988, pp. 900-906.

12 K. F. Purcell and J. C. Kotz, Inorganic Chemistry, W. B. Saunders Company Holt-Saunders Japan, Hong Kong, 1987, pp. 549-559.

13 H. F. Haarman, J. M. Ernsting, M. Kranenburg, H. Kooijman, N. Veldman, A. L. Spek, P. W. N. M. van Leuwen and K. Vrieze, Organometallics, 1997, 16, 887.

14 H. F. Haarman, F. R. Bregman, J. M. Ernsting, N. Veldman, A. L. Spek and K. Vrieze, Organometallics, 1997, 16, 54.

15 C. Piguet, B. Bocquet, E. Müller and A. F. Williams, Helv. Chim. Acta, 1989, 72, 323.

16 C. Piguet, E. Rivara-Minten, G. Hopfgartner and J.-C. G. Bünzli, Helv. Chim. Acta, 1995, 78, 1541; C. Piguet, J.-C. G. Bünzli, G. Bernardinelli, C. G. Bochet and P. Froidevaux, J. Chem. Soc., Dalton Trans., 1995, 83.

17 S. Petoud, J.-C. G. Bünzli, K. J. Schenk and C. Piguet, Inorg. Chem., 1997, 36, 1345.

18 F. H. Allen, O. Kennard, D. G. Watson, L. Brammer, A. G. Orpen and R. Taylor, J. Chem. Soc., Perkin Trans. 2, 1987, S1.
19 D. F. Shriver, P. W. Atkins and C. H. Langford, Inorganic Chemistry, Oxford University Press, Oxford, 1990, p. 342.

20 R. Cramer, Inorg. Chem., 1962, 1, 722.

21 C. K. Johnson, ORTEP II, Report ORNL-5138, Oak Ridge National Laboratory, Oak Ridge, TN, 1976.

22 A. G. Orpen, L. Brammer, F. H. Allen, O. Kennard, D. G. Watson and R. Taylor, J. Chem. Soc., Dalton Trans., 1989, S1.

23 Y. Takenaka and K. Osakada, Bull. Chem. Soc. Jpn., 2000, 73, 129.

24 J. K. M. Sanders and B. K. Hunter, Modern NMR spectroscopy, 2nd edn., Oxford University Press, Oxford, 1997, pp. 160-166; L. Di Bari, G. Pintacuda, P. Salvadori, R. S. Dickins and D. Parker, J. Am. Chem. Soc., 2000, 122, 9257.

25 C. Piguet, G. Bernardinelli and A. F. Williams, Inorg. Chem., 1989, 28, 2920.

26 S. Rüttimann, C. Piguet, G. Bernardinelli, B. Bocquet and A. F. Williams, J. Am. Chem. Soc., 1992, 114, 4230.

27 S. Rüttimann, C. M. Moreau, A. F. Williams, G. Bernardinelli and A. W. Addison, Polyhedron, 1992, 11, 635; X. Xiaoming, M. A. Haga, T. Matsumura-Inoue, Y. Ru, A. W. Addison and K. Kano, J. Chem. Soc., Dalton Trans., 1993, 2477; W. Shuangxi, Z. Ying, Z. Fanggie, W. Qiuying and W. Liufang, Polyhedron, 1992, 11, 1909; V. Shklover, H. Berke, I. L. Eremenko, R. Nesper, S. M. Zakeeruddin, Md. K. Nazeeruddin and M. Grätzel, Inorg. Chim. Acta, 1994, 219, 11; K. Wang, M. A. Haga, H. Monjushiro, M. Akiba and Y. Sasaki, Inorg. Chem., 2000, 39, 4022 .

28 S. Clemente, G. Bernardinelli and A. F. Williams, Poster Session, 34th ICCC, Edinburgh, 2000.

29 C. Piguet, J.-C. G. Bünzli, G. Bernardinelli and A. F. Williams, Inorg. Chem., 1993, 32, 4139.

30 K. Kanki, Y. Misumi and T. Masuda, Macromolecules, 1999, 32, 2384; T. Aoki, Y. Kobayashi, T. Kaneko, E. Oikawa, Y. Yamamura, Y. Fujita, M. Teraguchi, R. Nomura and T. Masuda, Macromolecules, 1999, 32, 79 and references therein. 